UNIVERSITY OF CHITRAL JOURNAL OF LINGUISTICS AND LITERATURE

VOL. 3 | ISSUE II | JULY - DEC | 2019

ISSN (E): 2663-1512, ISSN (P): 2617-3611

\title{
A Psychological Journey Of Optimistic/Pessimistic Cycle In The Fault In Our Stars
}

Muntazar Mehdi

Assistant Professor of English, NUML, Islamabad, Pakistan

mmehdi@numl.edu.pk

Hafsa Azhar

MPhil Scholar, NUML Islamabad, Pakistan

\begin{abstract}
This paper attempts to explore the presence of Freud's psychoanalytical tools- id, ego and superego and their role in determining the protagonists' optimistic/pessimistic cycle towards life. The researcher has applied Psychoanalysis theory of Sigmund Freud to analyse the novel. The research has successfully revealed application of Freudian psychoanalytical tools. Moreover, the researcher has also unveiled the psychological drives which were evident during the optimistic/pessimistic cycle of protagonists' lives. The researcher has concluded her research on the ground which illustrates when protagonists were having positive approach towards life, the working of superego in their life was indicated and while having pessimistic approach in their life witnessed the presence of id.
\end{abstract}

Key words: Psychoanalysis, Sigmund Freud, Optimism, Pessimism, Id, Ego, Superego.

\section{Introduction}

The novel, The Fault in Our Stars is a novel about the teenager couple, who fell in love and were suffering from the fatal and inevitable disease. Any disease chooses its victim regardless of social status and age. With every disease, there comes another element which is known as suffering and in this piece of literature/ fiction suffering is an unalterable part of their lives especially Hazel, Augustus and Isaac. They have suffered physically as well as emotionally. The writer through the character of Augustus shows that grief does not change you it just unmasks every human being who is having any kind of grief in his/her life. It is a novel about love, loss and pain. All these pains are the part and parcel of living or maybe the side effect of living as Hazel Grace Lancaster says in the novel that depression is the side of effect of dying.

Right from the beginning, Hazel being a patient of stage IV Thyroid cancer was of the view that depression is not the side effect of cancer but in actual is a side effect of dying. Being obsessed with this idea that after few days or years she will be no more she all the time thinks about what will be the impact of her death on everyone around her especially her parents and Augustus. The fact that she will be dead soon was all the time in her subconscious. It affected her outlook towards 
UNIVERSITY OF CHITRAL JOURNAL OF LINGUISTICS AND LITERATURE

life as she considers herself a grenade. A grenade that will soon explode and will destroy everything in its range. By considering herself as a grenade she just wants to minimize the number of causalities so she distanced herself from the real world especially Augustus Waters. Hazel was most of the time worried about her parents especially her mother. When Hazel was in the hospital she once heard her mother saying that would not enjoy being a mother anymore and this thought remained in her sub-conscious throughout her life.

Augustus Waters, a male character in the novel, was a tall and handsome young boy of seventeen years with blue eyes. He was another victim of a fatal disease named as osteosarcoma caused him to lose his right leg. Hazel met Augustus in one of the Support Group meetings which she attended on her mother insistence. Augustus was in that meeting, too, supporting his friend, Isaac, whose another eye is going to be removed soon due to cancer. In the support group meeting, Augustus told that he fears oblivion. Later on, on this topic, he had a discussion with Hazel. This discussion was the first milestone towards their love story as after this they met time and again. After the meeting they agreed to read each other favourite books. Augustus after reading the Novel, An Imperial Affliction which Hazel gave him became very upset because of its abrupt ending as the protagonist of AIA, Ana died.

Hazel explained her magnificence of An Imperial Affliction; a story of a 13 years old girl Anna, who was a cancer patient who eventually died. The novel ends in a midsentence and this is the way how a person dies. According to Hazel, this book portrays death truthfully, as in the novel she said, "You die in the middle of your life, in the middle of a sentence."(John Green, 2012, $p$. 67). This is what she thinks about herself that she will die in the same manner. Augustus wants to do something in his life that will leave a mark on the world. At the same time he fears that he will not be able to do so. When his cancer was cured, he has got a very positive outlook towards the life by enjoying his life and helping Hazel to stop thinking about gloomy things such as death. The moment his cancer returned his outlook towards life, got changed he got upset with the fact that soon he will die. As he would not be able to do anything remarkable in this world so will be forgotten by the people.

\section{Problem Statement}

The researcher intends to explore the psychological aspects (of Freud's psychoanalysis theory). The focus of this study is on the elements in Freudian psychoanalysis (Id, Ego, Superego) which are evident in the novel whether the journey is from optimism to pessimism or vice versa. The researcher has analysed the text in order to clarify the hidden psychological aspects of protagonists (Hazel and Augustus) to figure out for them what life is?

\section{Significance of the study}

This study will be beneficial for all those new researchers who aim at finding how a person's psyche will change over the passage of time i.e., from being a pessimist to being an optimist, as 
UNIVERSITY OF CHITRAL JOURNAL OF LINGUISTICS AND LITERATURE

this will be under consideration. Moreover, it would be relatable for readers if anyone in their acquaintances is suffering from a fatal disease and is having a pessimist approach towards life. It would be helpful for people who are interested in novel reading and who have the urge for the better understanding of literature because the research will develop an understanding between the reader and the ideas of the author which will help the reader to get the proper idea of the novels.

\section{Research Objective}

To investigate how the psyche of an individual affects him/her to an extent that his/her perspective about life changes from pessimism to optimism and vice versa.

\section{Research Questions}

1. How has the author knitted the instances of pessimism and optimism together in his novel?

2. What is the psychological effect of these -isms on the mind and life of major characters i.e., Augustus and Hazel?

\section{Delimitations}

This angle of study has been narrowed down to the novel The Fault in our Stars by John Green exploring the psychological aspects.

\section{Literature Review}

This segment of the article entails the works and researches done by earlier researchers on the topic of psychoanalysis. The researcher has tried to substantiate her own views with reference to the works already done.

Paris (1974), in his book A Psychological Approach to Fiction asserts that psychology enables one to talk about what the author knows, but his works help us to know what the psychologist is talking about...(Preamble).

The answer to the question why the theory of psychoanalysis is widely used in the study of literature as psychology and the theories of psychoanalysis talk about human beings in conflict with themselves and one another. Literature depicts and is written and read by such people. Different characters of different novels to highlight different psychological aspects.

Al-Tibi (2012) in his article discussed the mentality of Poe's characters in his short story, The Fall of the House of Usher. Characters in a literary work are representing writer's mind in one way or in another. In this article, Al-Tibi has talked about Roderick, Madeline and the narrator of the story and have applied Sigmund Freud's Iceberg theory. According to Al- Tibi's finding in his article, he concluded that in this story, Roderick is a representative of id as he was imaginative and quickly jumps up to the conclusions. Madeline is representing such ideas which cannot be expressed and the narrator had played the role of presenting superego. Freudian's id is active even when an individual is asleep. Here in this case, id in the shape of dreams urges the individual to do whatever he/she wants. Masculine ego is shown as a tool to take women back to the stereotypical role assigned by the social world. 
UNIVERSITY OF CHITRAL JOURNAL OF LINGUISTICS AND LITERATURE

Esmaeil Zohdi (2015) in his research has thrown light upon the characters especially the dreams of Carla and three steps Freud's theory i.e., id, ego and superego. In the analysis portion, He has pointed out the instances that how in her dreams she had all those thing for which she was longing in her living real life i.e., to have a new identity of being an independent individual. She was living a very repressed life so in her dreams her wish for being free became real. Zohdi summed up his work by saying, Flora is the representing id because it was encouraging her to go for freedom like the one she had in her dreams. Due to this, Clara was always in doubt as she was hanging in between the reality of her social position and her dreams. Clark (another character) goes with ego as he forced his wife back into the stereotypical role assigned to women by this male-dominated society. Furthermore, Sylvia is the embodiment of superego as she says that Carla's will be happy if she will stay with her husband instead longing for a thing which she could never have because of social norms.

Sara Assad Nassab (2016) in her research paper observed that the journey of Marlowe was considered as a psychological journey as both the main characters i.e., Marlow and Kurtz were hypnotized by the unexplored Africa. Nassab suggested that

Marlow, according to psychoanalytical theory of Freud, represents 'ego' whereas Kurtz stands with 'id'. He has let his inner demons control his outer self in the African Jungle. The research tried to describe this novel as a voyage towards self-discovery. Kurtz has depicted the demonic side of a human. In every human, there exists always an ability for evil but is repressed by the social pressure. Over here, Nassab has suggested that Kurtz who has the desire to satisfy his inner devilish instinct by doing so he becomes a symbol of id whereas, Marlow stands for ego as his inner instincts were not as dominant over him as in the case of Kurtz.

Shumei Gao (2006) in his work has described the main characters of Wuthering Heights by Emily Bronte as whose character is a representative of id and who represents ego and super-ego. Gao after examining the three character of the novel, came to the conclusion; Heathcliff is a symbolic figure of id as throughout the course of novel he does whatever he wants. Id is illogical clarified from the instances when Heathcliff takes revenges and ignored the aspects of morality and law .Ultimately it leads to harmful results as Heathcliff killed himself because his id was timeless. "[A]nd his unconscious impulse had made him do all the things to make feel satisfied"(Shumei gao, 2006, p.8) Catherine is representing ego; one of the essential element in Freud psychoanalysis theory. She was among few people who cannot go against society and therefore submit themselves in the hands of society. In her childhood, her id was a dominant part of her personality. When she was an adult, ego dominated her personality. Her feelings towards Heathcliff was a result of their similar dominant aspect i.e, id not because of some physical aspects. According to Freud, superego is the superior part of one's personality. The researcher has suggested that the author has shown the element of super-ego through the personality of Edgar Linton.

The main aim of analysis is to put forward the intentions of the author which are not expressed by the author directly. Many research articles have also been written in order to understand the 
UNIVERSITY OF CHITRAL JOURNAL OF LINGUISTICS AND LITERATURE

motives of the author. Analysis of a novel is done for many purposes. Research is researcherdependent as it only focuses on what the researcher wants to explore.

The psychological approach helps us to understand the meaning of a literary text because the characters in the novel are in actual representing author's imagination. As imagination is more powerful than the knowledge itself.

Korth(1981) in a chapter of his work entitled Unconscious Behaviour and Freudian Slips has given a stance that, anything which is forcefully suppressed into the unconscious mind will at some stage of life, affects the life of that particular individual of which the individual would be completely unaware of. (p.33).

$\mathrm{Na}$ and Do (2016) in their paper aimed at finding out the main psychological issues by using Sigmund Freud theory of psychoanalysis. By using descriptive method and qualitative approach along with the application of psychoanalysis theory, the paper was concluded with the finding that on the part of Hazel (protagonist) this novel witnessed self-defence evidences. The cause of selfdefence could be traced from her childhood. The paper claimed this novel as an incomplete psychological novel as the researcher was unable to find out the instances as to how Hazel developed her Berliore issues.

Isaoglu (2015) in his paper by using Freud's theory of psychoanalysis, tries to find out the reasons behind the abnormal behaviour of human. According to Freud all the three drives i.e., id ,ego and superego plays a very significant role in personality development and by studying these three in details one will understand the main reasons leading to the mental disorders as all they are interconnected. By analysing the novel, the researcher finds out that the characters in this novel has a direct relationship with the three drives but when the researcher has seen this psychological aspects with his highly critical spectacles then he concluded that these three drives are not in harmony as at some place their id is dominant and at some other point ego and so on. This lack of consistency brought perplexing results on the part of each character. Hester was isolated initially. Dimmesdale is unable to counter his conscience and ultimately punishes himself privately to ease the pain and grief from which he is suffering. Chillingworth never ending feeling of uncontrollable anger and resentment.

Amber Ashfaq (2016) in her research article has examined the power of love because of which the protagonist, Hazel had understood the real meaning of life by the love of Augustus which played a role of protector and healer. His love gave her the power to face the bitter reality i.e., facing the death of loved one with a smile on face. The theoretical framework which she used was that of Hazart Inyat-Ullah, According to this theorist, love makes you master or saint as love is a positive force in a person's life. Ashfaq here says in her article that love has made Hazel a saint as she decided to live for others after the death of her Love - Augustus.

Iqra Naeem(2016), in her article has analysed the behaviour of two protagonists towards life and death by doing a comparative analysis by using Arnold's theory of comparative analysis. She concluded her research with the following findings that attitude of both the characters changes 
UNIVERSITY OF CHITRAL JOURNAL OF LINGUISTICS AND LITERATURE

throughout the course of the novel as the approach of Hazel towards life was transformed from pessimism to optimism and approach of Augustus towards life was other way round.

Many critics have analysed Green's Novel as well .The thematic study of this novel has already been explored in the past few years. The analysis of characters has been worked upon too but the present research paper differs from all the previous researches carried out on the topic of psychoanalysis. Here researcher has analysed the novel keeping in mind the character of Hazel and Augustus with respect to their journey of life.

The researches that have been mentioned above are representing an individual either as an embodiment of id, ego or superego. In an individual, all the three instincts i.e. id, ego and superego are present and are evident at different stages of life and its growth. The previous researches reflected that a single person is a representative of only one instinct which can either be id, ego or superego. However, in the current study, the researcher has focused on the way of life of both Hazel and Augustus that revolves around optimism/pessimism cycle. Particularly, which of the elements of the current theory have been visible in the characters in form of positive or negative attitude towards life. Fictitious work has commonly been termed as imaginary as "The New Standard Encyclopedia fiction" defines narrative "a result of author's own imagination". (p. 89 90).

\section{Research Methodology}

It is a descriptive research with a qualitative approach and is limited only to the novel The Fault in our Stars. Qualitative method has a purpose to explain the motives of researcher in depth. Research has been carried out by analysing the psyche of the major characters i.e., Hazel Grace Lancaster and Augustus Waters.

\section{Research Design}

This research is a qualitative research. The data for this research has been analysed using a descriptive method. Relevant instances from the novel supporting the objectives of the researcher were collected and analysed according to the Freudian psychoanalysis theory.

\section{Theoretical framework}

To conduct the research of analysing psychological aspects involves during optimistic/pessimistic cycle on the part of main characters in the novel; Hazel and Augustus.

The research has used theory of psychoanalysis of Sigmund Freud to the idea of personality that how the two main characters have taken their journey of pessimistic/optimistic cycle through the novel.

Freud (1923) observed that the human psyche constitutes of three elements (i.e. tripartite) the id, ego and superego. He says that our unconscious mind influences the working of our conscious mind.

\section{Id, Ego and Superego}


UNIVERSITY OF CHITRAL JOURNAL OF LINGUISTICS AND LITERATURE

These are the three components of human mind the conflict arises when unconscious mind takes control of the conscious and ego cannot keep the balance ego is directly connected with the reality and pressure is exerted on ego by the id.

The id is impulsive and a desire driven part of personality the id wants all of its desires to be fulfilled and it works on pleasure principle as described by Freud (Freud, 1920), whereas, the ego works according to Freud on reality principle it tries to balance the demands of the unconscious with what is practical. The superego is not realistic at all it can demand the moral actions that might bring a harm. The id is not realistic as well as its demand is to fulfil its desires without the fear of consequences. The id balances both of them and tries to keep both the parts of mind work according to what is practically right (Hayes, 2000).

Ego is 'that part of the id which has been modified by the direct influence of the external world.' (Freud [1923], 1961, p. 2)

Freud (1923) asserts that the id is a horse and the ego is the rider. So, ego is "like a man on horseback, who has to hold in check the superior strength of the horse. (p.15).

Super-ego is the exact opposite to the id. It also tries to influence ego to follow moralistic path rather than giving up to the id.

\section{Data Analysis}

Many people have done the analysis of many novels according to their own understanding. Here researcher is going to analyse the text of the novel with reference to the psychoanalytical theory by Freud because of the undeniable fact that whenever a person reads a piece of literature he understands the concept.

This section of the paper emphasizes on the psychological state of the two main characters of the novel i.e., Hazel Grace Lancaster and Augustus Water. It depicts that which of the three essential element (id, ego and superego) in Sigmund Freud's theory of psychoanalysis are present during the course of novel and which force is influential when the character either has a positive outlook towards life or having a negative outlook.

Late in the winter of my seventeenth year, my mother decided I was depressed, presumably because I rarely left the house, spent quite a lot of time in bed, read the same book over and over, ate infrequently, and devoted quite a bit of my abundant free time to thinking about death. (Green, 2012; p.3)

John Green started his masterpiece with a pessimistic approach towards life as depicted by Hazel Grace when she mentions her act of hardly leaving her place. One confines oneself to one's house when one is unable to decide whether to go with id or superego so ends up with ego and in her case she preferred to stay at home and continued up with her monotonous routine. As she knows that she will die soon so she wants to stay away from the external world by staying at home and not meeting anyone. One of the major instances to support pessimism in terms of Hazel is that she has plenty of time to think about death as she has accepted the reality of her life that she is going to be dead. 
UNIVERSITY OF CHITRAL JOURNAL OF LINGUISTICS AND LITERATURE

Whenever you read a cancer booklet or website or whatever, they always list depression among the side effects of cancer. But, in fact, depression is not a side effect of cancer. Depression is a side effect of dying. (Cancer is also a side effect of dying. Almost everything is, really.) (Green, 2012; p.3)

It was in her subconscious mind that she will die soon and this has made her an extremist in terms of being a pessimist. Thinking about death is a component of superego. As id will always give you ideas that are pleasurable and death is a painful experience, however, superego will always give you lectures on the extreme realities of life. It is not considered good or appreciable to think about death while you are alive so following her superego she said so as it was very difficult for her to face the extreme and harsh realities of life. She feels, that she is depressed not because she is diagnosed with cancer but because she knows that she will be dead soon and this increased her depression:

I wanted to make my parents happy. There is only one thing in this world shittier than biting it from cancer when you're sixteen, and that's having a kid who bites it from cancer.(Green, $2012 ;$ p.8)

Although she was depressed, still she was worried about her parents that shows the good side of her character i.e. ego. She started caring for her parents in a very realistic manner because she knew she will die soon. By accepting this reality she started caring for her parents. If she cared for them more than her own life, then it would be superego. Being a pessimist, she can still find some aim in her life and cares about her parents as she is their only hope. She feels sad while thinking about the time when her mother would not have anyone to call her According to Hazel, there is nothing worse in this world than having the only child who is dying of such a fatal disease at a very early age.

"And I've never lit one. It's a metaphor, see: You put the killing thing right between your teeth, but you don't give it the power to do its killing." (Green, 2012; p.20)

These lines are by Augustus Waters; who is a foil to Hazel Grace not only in terms of character but in terms of his thinking process too. He played a role exact opposite to Hazel. He was a cancer survivor, but he did not let his past or subconscious thoughts ruin his present. He had a very positive outlook towards life. These lines are showing the aspect of superego because he did not let his past experience of dying of cancer ruin his cancer-free present. Although during cancer, he had lost his one leg still he is a very optimist person. He is of the view that nothing can harm you if you do not allow that thing to harm you. According to him, getting harmed or not is in our hands. He clarified his view by putting the cigarette in between his lips and did not light it up as he did not light it up so it cannot harm him. "I want to minimize the number of deaths I am responsible for," I said (Green, 2012; p.28)

When Augustus was at Hazel's place, they were discussing about dinner and Hazel refused to have chicken in dinner. The reason she gave was that every chicken she will eat she will be held 
UNIVERSITY OF CHITRAL JOURNAL OF LINGUISTICS AND LITERATURE

countable for its death. This shows that how different she is from others by thinking about such a minor issue which is hardly noticed by anyone.

Although it is in her subconscious that she will die but the way she interacted with society i.e., ego.

These lines marked a change in her mental working as earlier, it is observed that she cared about her parents. Over here. she is thinking and caring about everything that she eats as over here she talks about a chicken. Caring for others is an act of kindness. Act of kindness and caring for others is an instance of the dominance of superego.

So I excused myself on the grounds of pain and fatigue, as I often had over the years when seeing Kaitlyn or any of my other friends. In truth, it always hurt. It always hurt not to breathe like a normal person, incessantly reminding your lungs to be lungs, forcing yourself to accept as unsolvable the clawing scraping inside-out ache of underoxygenation. So I wasn't lying, exactly. I was just choosing among truths. (Green, 2012; p.45)

Through these lines, Hazel is once again represented as a pessimist, owing to the fact that she is suffering from lung cancer. Due to this, she cannot breathe properly. Whenever she does something wrong she always has this excuse that she is dying of cancer. Satisfying her this negative instinct i.e., id, she uses her disease as an excuse as she was unable to overcome her id. The excuse she gave was that she does not consider it as a lie but she satisfies herself by saying that she was just choosing among few opinions of truth.

That's part of what I like about the book in some ways. It portrays death truthfully. You die in the middle of your life, in the middle of a sentence. But I do-God, I do really want to know what happens to everyone else. That's what I asked him in my letters.(Green, 2012; p.67)

Hazel likes a book titled as An imperial Affliction a lot. She liked this book because it is about a girl who lost her life because of cancer. Hazel was unable to control herself from thinking about death. She cannot control her id and to face the real world and enjoy her life till the time she has it. She has exchanged her book with Augustus and when he has read it she discussed the book with him. She told him the reason why she likes this book as it depicts death truthfully. Hazel was unable to take herself and her mental faculty out of the concept of death and all the time she talks about death. Her personality is dominated by her id i.e., being a pessimist and a depressed individual while interacting with others.

I imagined sitting at a sun-drenched café with Peter Van Houten as he leaned across the table on his elbows, speaking in a soft voice so no one else would hear the truth of what happened to the characters I'd spent years thinking about. He'd said he couldn't tell me except in person, and then invited me to Amsterdam. I explained this to Mom, and then said, "I have to go." (Green, 2012; p.79)

Whenever she reads her favourite book 'An Imperial Affliction' her id dominates her personality. In order to give her id a stand on physical ground, she wants to go to Amsterdam as the writer has 
UNIVERSITY OF CHITRAL JOURNAL OF LINGUISTICS AND LITERATURE

invited her a nd Augustus to meet him. Hazel was going as she wants to satisfy her id by knowing what happened after the novel ended as it had an abrupt ending because of Ana's death- the narrator of 'An Imperial Affliction'. She wants to know what had become of Ana's mother (Ana is the one who died because of cancer). Although, she knew that being a patient of lungs cancer she cannot travel but to satisfy her id she was willing to do so. She was fearless of death while going to Amsterdam/ travelling to Amsterdam. "I am. I didn't cut this fella off for the sheer unadulterated pleasure of it, although it is an excellent weight-loss strategy. Legs are heavy!'(Green, 2012; p.83) These lines stand as one of the best example of Augustus being an optimist person. Although he had harsh memories of cancer. Due to this disease, he has lost one leg but he did not get sad over losing it. He has a healthy ego. Although he was a basketball player he did not let his past harsh memories to ruin his cancer-free present, therefore, has a very optimistic attitude towards life. He knew that crying over spilt milk is useless what is gone is gone he cannot have his leg back so he started living his life with one leg happily by saying that legs are heavy.

"I'm like. Like. I'm like a grenade, Mom. I'm a grenade and at some point I'm going to blow up and I would like to minimize the casualties, okay" (Green, 2012; p.99)

By calling herself a grenade, she is unable to keep her mind off from death which is approaching her. Working of superego is evident as by calling herself a grenade she wants to save others. Here, her caring and sensitive nature is seen when she says that she will minimize the number of people who will be affected by her death. She is not concerned about her pain/ suffering but is concerned with the pain that her relatives more specifically her parents will face. Taking into consideration, ther caring nature it will be analysed as the working of superego as it is the exact opposite of id(by calling herself as a grenade) whereas by caring for others shows her mental condition that although she is depressed and pessimist but still she cares for others.

"I'm a grenade," I said again. "I just want to stay away from people and read books and think and be with you guys because there's nothing I can do about hurting you; you're too invested, so just please let me do that, okay? I'm not depressed. I don't need to get out more. And I can't be a regular teenager, because I'm a grenade. (Green, 2012; p.99)

Being a cancer patient, she is a pessimist still she cares for the ones who cares for her. Here working of her ego is seen (a balance between id and superego). She decides that in order to minimize the number of causalities she would simply stay at home and read some books. She knows that she is a grenade not a normal teenager who can enjoy life. She considers herself as a grenade which is a tool of destruction. She depicts that as grenade destroys the place where it bursts in the similar manner her death will bring destruction in the life of those who loved her as it will destroy her parents and all her dear and loved ones.

“Cause I'm just - I want to go to Amsterdam, and I want him to tell me what happens after the book is over, and I just don't want my particular life, and also the sky is depressing me, and there is this old swing set out here that my dad made for me when I was a kid." (Green, 2012; p.121) 
UNIVERSITY OF CHITRAL JOURNAL OF LINGUISTICS AND LITERATURE

Being a victim of lungs cancer, she was not suitable for a distant travelling but still she wanted to go to Amsterdam just to fulfil her useless desire of knowing what happened to Ana's family after her death. This is the working of her id that now she only wants to know what has happened with Ana's family. She felt uncomfortable till the time her desire was not fulfilled. The sky was depressing for her even on the swing which she always felt comfortable and relaxed on. It is now making her uncomfortable. Just to get this desire of her id fulfilled she afterwards went to Amsterdam.

Much of my life had been devoted to trying not to cry in front of people who loved me, so I knew what Augustus was doing. You clench your teeth. You look up. You tell yourself that if they see you cry, it will hurt them, and you will be nothing but A Sadness in their lives, and you must not become a mere sadness, so you will not cry, and you say all of this to yourself while looking up at the ceiling, and then you swallow even though your throat does not want to close and you look at the person who loves you and smile. (Green, 2012; p.213-214)

Towards the end of their trip to Amsterdam, Hazel was told by Augustus that his cancer has reappeared. Upon hearing this bad news, she didn't start complaining in fact she started to stay positive to be a positive force in his life. In these lines, she is once again thinking about others which shows, the working of ego which balances her personality and enables her not to be selfish and not be ignorant/numb towards others by doing whatever she wants and wherever she wants. Working of her superego is evident, when she clearly says that you cannot cry whenever you are hurt especially not in front of those who love you because it will hurt them. It is easy to feel pain by one's own self instead of watching others in pain because of you so you can get yourself hurt but you should never hurt others more specifically the one who loves you.

"The world," he said, "is not a wish-granting factory," (Green, 2012; p.214)

Augustus Waters, the one who has used his last wish to visit Amsterdam for Hazel and his wish got fulfilled as he went there. Using his last wish for Hazel is linked with superego as he was thinking about Hazel's happiness. He says that world is not a wish-granting factory you cannot get whatever you want. This sentence marks the transformation in the character of Hazel Grace as well as Augustus Waters. Augustus after being diagnosed as a cancer patient again his approach towards life transformed into pessimism from optimism as witnessed earlier when he was a cancer survivor. He didn't let his pessimist past ruin his present life; a life free of cancer. Over here, the case is exact opposite now as the novel proceeds working of his id will be evident because he knew that now he will be in dust soon like many other cancer patients.

What am I at war with? My cancer. And what is my cancer? My cancer is me. The tumors are made of me. They're made of me as surely as my brain and my heart are made of me. It is a civil war, Hazel Grace, with a predetermined winner. (Green, 2012; p.216)

Augustus Waters, by saying that he is at war with his cancer as for him, his cancer is not a disease but he himself is killing himself. Over here, he has used the word cancer in a metaphorical manner. 
UNIVERSITY OF CHITRAL JOURNAL OF LINGUISTICS AND LITERATURE

This instance is highlighting the dominance of his id as his cancer is none other than his own id. The work of id is to have every single desire of heart and brain get fulfilled no matter how illogical the demand of id maybe. The way he called it a predetermined winner this will be evident in the upcoming instances that Augustus' id will take over his ego and superego and he will be doing whatever comes to his mind without giving a single thought to the consequences of such demands.

"I wanted to buy a pack of cigarettes," he mumbled. "I lost my pack. Or they took it away from me. I don't know. They said they'd get me another one, but I wanted . . . to do it myself. Do one little thing myself." (Green, 2012; p.244)

Upon hearing the news that cancer of Augustus has returned. His parents took his cigarettes away from him by saying that, they will buy him another one. He did not want others to do his works. This is the evidence of working of his id as he wanted cigarettes, which are not good for him, so instead of waiting for his parents to get him one he himself went outside in that miserable condition to fetch it to satisfy himself. "I hate myself I hate myself I hate this I hate this I disgust myself I hate it I hate it I hate it just let me fucking die.” (Green, 2012; p.245)

This is how Augustus has interpreted his weakness, being a weak person he cannot do what he wants to do and cannot go where he wants to go. The working of his id is seen when he went out at night to have a pack of cigarette when he already knew that his condition is not favourable for such activity. Over here, his id is seen as he started to hate himself due to the fact of being unable to do anything on his own and thus unable to satisfy the desire of his id i.e., of doing something for his own self.

'I'm hopeful I'll get to attend as a ghost, but just to make sure, I thought I'd- well, not to put you on the spot, but I just this afternoon thought I could arrange a prefuneral..." (Green, 2012; p.257)

Fully aware of the fact that he will die soon, he plans to arrange a prefuneral for himself. Instead of letting things happen in their natural way at the desired time. His personality being dominated by id, therefore, he arranged his prefuneral because he wanted to do so. He did not even give a single thought regarding the feelings of Hazel and Isaac that how they will utter such sentences which they have to say when he will be no more with them. Saying such sentences by considering Augustus as a dead person when he was alive; was the toughest task for both Isaac and Hazel but they did it for Augustus as they both cared for him but he was not bothered about it and he wanted his id to get fulfilled and this is what he did. He gained satisfaction by causing pain to Isaac and Hazel whom he once cared a lot.

In the next part, the researchers have concluded their research by mentioning the findings and outcomes that answered the research questions.

\section{Conclusion}

The research is concluded with the findings that the writer has knitted the instances of optimism and pessimism side by side. When Hazel was a pessimist, she had an inspirational force named as Augustus Water. Gradually, due to his presence in her life she became an optimist. In her case, she 
UNIVERSITY OF CHITRAL JOURNAL OF LINGUISTICS AND LITERATURE

needs someone who can bring her back to life, and that someone turns out to be none other than blue-eyed Augustus Waters.

In terms of Augustus' character, it was just cancer that changed his approach towards life. When he was a cancer survivor, he became optimist and when it was diagnosed that the silent killercancer has entered his body once again, he became a pessimist. It was just his fatal disease due to the presence of which he got a pessimistic approach towards life.

The psychological effects of these -isms (optimism and pessimism) on the psyche of Hazel and Augustus are observed too. When both of the characters (Hazel Grace and Augustus Waters) are having an optimistic approach towards life, the working of their superego is witnessed; one of the essential elements in Freud's theory of psychoanalysis. Moreover, when they had a pessimistic approach towards life, working of their id was evident because they knew that they were going to die, so what they wanted and wished to attain by hook or by crook they did such as, Augustus arranged his pre-funeral ignoring the fact that it will hurt Isaac and Hazel a lot.

John Green has sketched the plot of the story in a way that even in the every hopeless situation there was always a ray of hope and happiness. When Hazel was all the time thinking about her death, then, at that time in this hopeless situation Augustus performed the role of hope. He was the only one who took her from this hopeless situation. Similarly, when Augustus was obsessed with the fact that he will die soon at that time it was Hazel who stood by his side and sympathized with him although she too knows that her Gus will soon leave this world.

The analysis has shown how psyche of an Individual affects his perception of life. Through the characters of the novel, the writer has very artistically presented the psychological representation of life. This exploration has brought about different levels of understandings. The foremost contribution of this research is that it has enabled us to understand in a better way the working of human psyche when a person is having positive and negative view towards life.

This research will also open new dimensions of analysis and will be assisting those researchers who intend to study the psyche of individuals in terms of the optimistic/pessimistic cycle of their lives.

\section{References}

Al-Tibi, Bahaa Aldin H. (2012). Applying Sigmund Freud's Iceberg Theory to Edgar Allan Poe's Short Story "The Fall of the House of Usher".

Ashfaq, Amber. (2016). Love as a strength: A thematic study of the novel "The Fault in Our Star" by John Green.

Freud, S. (1920). Beyond the pleasure principle. SE, 18: 1-64.

Freud, S. (1923). The ego and the id. SE, 19: 1-66.

Freud, Sigmund. (1909). The Interpretation of Dreams. Ed. Britannica: Clark University. Gao, Shumei. (2006). An Analysis of Emily Bronte's Wuthering Heights on the Angle of Psychology. 
UNIVERSITY OF CHITRAL JOURNAL OF LINGUISTICS AND LITERATURE

İSAOĞLU, Hande. (2015). A Freudian Psychoanalytic Analysis of Nathaniel Hawthorne's The Scarlet Letter" International Journal of Social Science, JASSS2713 Number: 32, p. 499511, Winter III 2015

Hayes, N. (2000). Theories of Personality. In foundations of psychology (3rd ed., p. 203). Retrieved from https://www.bookdepository.com/Foundations-PsychologyNickyHayes/9781861525895

Korth, Leslie.O. (1981). "Unconscious Behaviour and Freudian Slips". The Power of Creative Imagination. Northamptonshire: A Thomas and Company.

McConnel, J. V. (1980) Understanding Human Behaviour. New York: Holt, et. al, Print.

McLeod, S. A. (2016). Id, Ego and Superego. Retrieved from www.simplypsychology.org/psyche.html

Naeem, Iqra. (2016). "Attitude towards Life and Death A comparative study of Hazel Grace and Augustus in The Fault in Our Stars"

Nassab, Sara Assad. (2006).A Postcolonial and Psychoanalytical Approach to Heart of Darkness. New Standard Encyclopedia. Chicago: Standard Ed. Co., Vol. 6.

Pangestu, Nathania Astria., \& Sunardi, F.X. Dono. (2016) An Incomplete Psychological Novel: a Psychoanalytical Analysis of Hazel Lancaster in John Green's The Fault in Our Stars, Phenomena Vol. 16 No. 1, 20-28.

Paris, B. J. A. (1974). Psychological Approach to Fiction. Bloomington and London: Indiana University Press.

Zohdi, Esmaeil., \& Bahador, Raheleh. (2015). Alice Munro's Runaway in the Mirror of Sigmund Freud, IJALEL, Vol. 4 No. 2, 169-176.

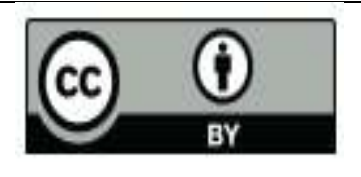

@ 2017 by the author. Licensee University of Chitral, Journal of Linguistics \& Literature, Pakistan. This article is an open access article distributed under the terms and conditions of the Creative Commons Attribution (CC BY) (http://creativecommons.org/licenses/by/4.0/). 